\title{
A Thermodynamic Analysis of Two Competing Mid-Sized Oxyfuel Combustion Combined Cycles
}

\author{
Egill Thorbergsson and Tomas Grönstedt \\ Division of Fluid Dynamics, Department of Applied Mechanics, Chalmers University of Technology, 41296 Gothenburg, Sweden \\ Correspondence should be addressed to Egill Thorbergsson; egill@chalmers.se
}

Received 4 September 2015; Accepted 21 December 2015

Academic Editor: Umberto Desideri

Copyright ( 2016 E. Thorbergsson and T. Grönstedt. This is an open access article distributed under the Creative Commons Attribution License, which permits unrestricted use, distribution, and reproduction in any medium, provided the original work is properly cited.

\begin{abstract}
A comparative analysis of two mid-sized oxyfuel combustion combined cycles is performed. The two cycles are the semiclosed oxyfuel combustion combined cycle (SCOC-CC) and the Graz cycle. In addition, a reference cycle was established as the basis for the analysis of the oxyfuel combustion cycles. A parametric study was conducted where the pressure ratio and the turbine entry temperature were varied. The layout and the design of the SCOC-CC are considerably simpler than the Graz cycle while it achieves the same net efficiency as the Graz cycle. The fact that the efficiencies for the two cycles are close to identical differs from previously reported work. Earlier studies have reported around a 3\% points advantage in efficiency for the Graz cycle, which is attributed to the use of a second bottoming cycle. This additional feature is omitted to make the two cycles more comparable in terms of complexity. The Graz cycle has substantially lower pressure ratio at the optimum efficiency and has much higher power density for the gas turbine than both the reference cycle and the SCOC-CC.
\end{abstract}

\section{Introduction}

The evidence that anthropogenically generated greenhouse gases are causing climate change is ever-increasing. The Intergovernmental Panel on Climate Change (IPCC) has stated that [1]:

"It is extremely likely that more than half of the observed increase in global average surface temperature from 1951 to 2010 was caused by the anthropogenic increase in greenhouse gas concentrations and other types of anthropogenic forcing together. The best estimate of the human induced contribution to warming is similar to the observed warming over this period."

One of the largest point source emitters of greenhouse gases is fossil fuel based power plants. One of the options to mitigate these greenhouse gases is to utilize Carbon Capture and Storage (CCS) in power plants.

There are three main processes being considered for CCS: the post combustion capture, the precombustion capture, and the oxyfuel combustion capture [2]. This paper focuses on the oxyfuel combustion combined cycle. The oxyfuel combustion fires fuel with nearly pure $\mathrm{O}_{2}$ instead of air and the resulting combustion products are primarily steam and carbon dioxide. This makes it technically more feasible to implement $\mathrm{CO}_{2}$ capturing solutions.

Two competing oxyfuel combustion combined cycles have shown promising potential [3]. These are the semiclosed oxyfuel combustion combined cycle (SCOC-CC) and the Graz cycle. Numerous studies have been done on both of these cycles, including a number of studies that have compared the performance of the two cycles [3-37].

1.1. SCOC-CC. The SCOC-CC is essentially a combined cycle that uses nearly pure $\mathrm{O}_{2}$ as an oxidizer. After the heat recovery steam generator (HRSG) there is a condenser that condenses the water from the flue gas. The flue gas leaving the condenser is then primarily composed of $\mathrm{CO}_{2}$. Part of the $\mathrm{CO}_{2}$ is then recycled back to the compressor while the rest is compressed and transported to a storage site.

Bolland and Sæther first introduced the SCOC-CC concept in [4] where they compared new concepts for recovering $\mathrm{CO}_{2}$ from natural gas fired power plants. They compared a standard combined cycle with a cycle using postcombustion 
both with and without exhaust gas recirculation and also the SCOC-CC, along with a Rankine cycle that incorporates oxyfuel combustion. Ulizar and Pilidis [5] were first to present a paper that focused exclusively on the performance of the SCOC-CC. They started with cycle optimization and also simulated off-design performance. They did more extensive work exploring the selection of an optimal cycle pressure ratio and turbine inlet temperature [6] and on operational aspects of the cycle [7]. Bolland and Mathieu also published studies on the SCOC-CC concept [8] comparing its merits with a postcombustion removal plant. Amann et al. [9] also compared the SCOC-CC with a combined cycle using a postcombustion plant and made a sensitivity analysis regarding the purity of the $\mathrm{O}_{2}$ and the corresponding energy cost of the air separation unit. Tak et al. compared the SCOC-CC with a cycle developed by Clean Energy Systems and concluded that the SCOC-CC seemed to be advantageous [10]. Jordal et al. proceeded to develop improved cooling flow prediction models [11] and Ulfsnes et al. studied transient operation [12] and further explored real gas effects and property modelling [13]. Other researchers have started with a conventional natural gas combined cycle as a starting point in the modelling of the SCOC-CC. Riethmann et al. investigated the SCOC-CC using a natural gas combined cycle as a reference case and concluded that the net efficiency of the SCOC-CC was 8.3\% points lower compared to the reference cycle [15]. Corchero et al. did a parametric study with regard to the pressure ratio at a fixed turbine entry temperature of $1327^{\circ} \mathrm{C}$ [14]. Yang et al. [16] modelled the SOCC-CC along with the ASU and the $\mathrm{CO}_{2}$ compression train at different pressure ratios and two different turbine inlet temperatures, $1200^{\circ} \mathrm{C}$ and $1600^{\circ} \mathrm{C}$. They concluded that the optimal pressure ratio is around 60 and 90 for the turbine inlet temperatures of $1418^{\circ} \mathrm{C}$ and $1600^{\circ} \mathrm{C}$, respectively. With optimal design conditions, the net cycle efficiency is lower than the efficiency of the conventional CC by about 8 percentage points for both of the two turbine inlet temperatures. Dahlquist et al. optimized a mid-sized SCOC-CC [17]. They concluded that although the optimum pressure ratio was 45 with regard to net efficiency, it would be beneficial to choose a lower pressure ratio for the cycle. Choosing a lower pressure ratio would only penalize the efficiency by a small amount but facilitate the design of the compressor by a great deal. Sammak et al. looked at different conceptual designs for the gas turbine for the SCOC-CC [18]. They compared a single and twin-shaft design and concluded that a twin-shaft would be an advantageous design for the SCOC-CC because of the high pressure ratio.

The main results of these papers have been summed together in Table 1. It is clear that there is no consensus in the power requirement of the air separation unit (ASU) as it ranges from 735 to $1440 \mathrm{~kW} /(\mathrm{kg} / \mathrm{s})$ based on the mass flow of the $\mathrm{O}_{2}$ generated. This can be explained partly by the fact that the purity of the $\mathrm{O}_{2}$ stream varies from $90 \%$ to $96 \%$ and also that compression of the $\mathrm{O}_{2}$ stream is included in the ASU energy demand in some of the studies. The pressure ratio (PR) varies considerably between studies, where the lowest is 24.5 while the highest is 90 . This can partly explain that only some of the studies aimed at optimizing the cycle with respect to pressure ratio, while others only selected a pressure ratio
TABLE 1: Cycle performance for the SCOC-CC from earlier papers.

\begin{tabular}{lcccccc}
\hline Paper & Year & $\begin{array}{c}\text { ASU } \\
\mathrm{kW} /(\mathrm{kg} / \mathrm{s})\end{array}$ & $\begin{array}{c}\text { Output } \\
\text { MW }\end{array}$ & $\begin{array}{c}\text { TIT } \\
{ }^{\circ} \mathrm{C}\end{array}$ & PR & $\begin{array}{c}\eta_{C} \\
\%\end{array}$ \\
\hline$[4]$ & 1992 & $1512^{\dagger}$ & 514.7 & & 30 & 41.4 \\
{$[5]$} & 1997 & & & 1200 & 48 & 47.26 \\
{$[6]$} & 1998 & & 193 & 1376 & 56 & 36.7 \\
{$[8]$} & 1998 & $900^{*}$ & 57.2 & 1319 & 30 & 44.9 \\
{$[37]$} & 2003 & $1440^{\dagger}$ & 250 & & 35 & 47.2 \\
{$[30]$} & 2004 & $972^{*}$ & 400 & 1328 & & 44.1 \\
{$[32]$} & 2007 & $812^{*}$ & 400 & 1328 & & 47 \\
{$[33]$} & 2008 & $1225^{\dagger}$ & 400 & 1400 & 40 & 49.75 \\
{$[15]$} & 2009 & & 329.7 & 1232 & 40 & 48.3 \\
{$[9]$} & 2009 & $861^{\dagger}$ & 396 & 1427 & 24.5 & 51.3 \\
{$[10]$} & 2010 & & 475.7 & 1400 & 40 & 53.9 \\
{$[35]$} & 2012 & $1225^{\dagger}$ & 106 & 1400 & 37 & 46 \\
{$[16]$} & 2012 & $1021^{\S}$ & 291.1 & 1418 & 60 & 48.2 \\
{$[16]$} & 2012 & & 473.8 & 1600 & 90 & 52.2 \\
{$[17]$} & 2013 & $735^{9}$ & 125 & 1340 & 34 & 47.21 \\
\hline
\end{tabular}

${ }^{\dagger}$ Delivery pressure from ASU is the operating pressure.

${ }^{*}$ Delivery pressure from ASU is $1 \mathrm{bar}$.

${ }^{\S}$ Delivery pressure from ASU is 27 bar.

${ }^{9}$ Delivery pressure from ASU is 1.2 bar.

based on, for example, experience. Corchero et al. [14] and Yang et al. [16] looked at different pressure ratios and show similar trends as has been found in the current study. The resulting efficiencies from these studies have a very large spread and ranges from $36.7 \%$ to $53.9 \%$. An important fact to take into consideration is that the oldest reference [4] is from 1992 and the state-of-the-art cycle efficiency for a combined cycle at that time was much lower than is today. Bolland and Sæther found that the combined cycle efficiency, without carbon capture, was around 52\% and that the SCOC-CC was around 10\% lower than the reference cycle. The studies that are presented in Table 1 are not based on the same assumptions, such as condenser cooling methods and turbine cooling which of course influence the net efficiencies reported.

1.2. Graz Cycle. The basic principle of the Graz cycle was developed by Jericha in 1985 [19] and was aimed at solar generated $\mathrm{O}_{2}$-hydrogen fuel. Jericha et al. modified the cycle in 1995 [20] to handle fossil fuels.

The Graz cycle, similar to the SCOC-CC, uses nearly pure $\mathrm{O}_{2}$ as oxidizer. In the Graz cycle a major part of the flue gas is recycled back to the compressor; that is, the water is not condensed out of it. Furthermore, the turbine and the combustion chamber are cooled using steam from the steam cycle. This means that the working fluid is mainly steam in the gas turbine. The other part of the flue gas goes through a condenser where the water is condensed from the flue gas. The flue gas is then in major parts $\mathrm{CO}_{2}$ which can be compressed and transported to a storage site. The full design of the Graz cycle incorporates a second bottoming cycle that uses the heat from the condensation of the flue gas. The second bottoming 
TABLE 2: Cycle performance for the Graz cycle from earlier papers.

\begin{tabular}{lcccccc}
\hline Paper & Year & $\begin{array}{c}\text { ASU } \\
\mathrm{kW} /(\mathrm{kg} / \mathrm{s})\end{array}$ & $\begin{array}{c}\text { Output } \\
\text { MW }\end{array}$ & $\begin{array}{c}\text { TIT } \\
{ }^{\circ} \mathrm{C}\end{array}$ & PR & $\begin{array}{c}\eta_{C} \\
\%\end{array}$ \\
\hline$[21]$ & 2002 & $1080^{\dagger}$ & 92.251 & 1400 & 40 & $57.51^{\ddagger}$ \\
{$[22]$} & 2003 & $900^{*}$ & 92.251 & 1400 & 40 & $55^{\ddagger}$ \\
{$[30]$} & 2004 & $972^{*}$ & 400 & 1328 & 40 & 42.8 \\
{$[26]$} & 2005 & $1355^{\dagger}$ & 100 & 1400 & 40 & 55.3 \\
{$[24]$} & 2005 & $900^{*}$ & 92.2 & 1312 & 40 & 52.5 \\
{$[32]$} & 2007 & $812^{*}$ & 400 & 1328 & 40 & 48.6 \\
{$[28]$} & 2008 & & 403 & 1400 & 40 & 53.12 \\
{$[29]$} & 2008 & $1225^{\dagger}$ & 597 & 1500 & 50 & 54.14 \\
{$[33]$} & 2008 & $1225^{\dagger}$ & 400 & 1400 & 40 & 53.09 \\
{$[35]$} & 2012 & $1225^{\dagger}$ & 106 & 1400 & 44.7 & 49 \\
\hline
\end{tabular}

${ }^{\dagger}$ Delivery pressure from ASU is the operating pressure.

${ }^{*}$ Delivery pressure from ASU is 1 bar.

${ }^{\ddagger}$ Energy cost for $\mathrm{CO}_{2}$ compression not taken into account.

cycle is a subatmospheric steam cycle, since the condensation returns low quality heat, that is, low temperature.

There has been extensive research at the Graz University of Technology in designing the cycle, but the main focus has been on design of the turbomachinery components [21-29]. These studies have not been focused on optimizing the cycle performance with respect to pressure ratio. The main results of papers that study the Graz cycle are shown in Table 2. The design of the Graz cycle has been evolving and the most advanced cycle layout is the S-Graz cycle which was presented in paper [26]. Publications published later all study the SGraz cycle concept.

1.3. Comparison of Cycles. A number of papers have compared the two different cycles along with other carbon capture technologies for natural gas fired power plants [30-36]. The main results of papers that present cycle results are shown in Tables 1 and 2. Kvamsdal et al. compared nine different carbon capture options for natural gas fired power plants [30, 32]. Among them were the SCOC-CC and the Graz cycle; the results for the cycle simulations are shown in Tables 1 and 2. It was concluded that concepts that employed very advanced technologies that have a low technological readiness level and high complexity achieved the highest performance. Franco et al. evaluated the technology feasibility of the components in 18 different novel power cycles with $\mathrm{CO}_{2}$ capture [31]. One of the conclusions was that the SCOC-CC would be one of the cycles that incorporates gas turbines that would require the least effort to turn into a real power plant. Sanz et al. made a qualitative and quantitative comparison of the SCOC-CC and the Graz cycle [33]. Their thermodynamic analysis showed that the high-temperature turbine of the SCOC-CC plant needed a much higher cooling flow supply due to the less favourable properties of the working fluid than the Graz cycle turbine. They, in comparison to Franco et al. [31], concluded that all turbomachines of both cycles showed similar technical challenges and that the compressors and hightemperature turbines relied on new designs. Woollatt and
Franco did a preliminary design study for both the compressor and the turbine, in both the SCOC-CC and the Graz cycle [34]. They concluded that the turbomachinery can be designed using conventional levels of Mach number, hub/tip ratio, reaction, and flow and loading coefficients. They furthermore concluded that the efficiencies and the compressor surge margins of the components should be similar to a conventional gas turbine. Thorbergsson et al. examined both the Graz cycle and the SCOC-CC [35]. They conceptually designed the compressor and the turbine for both cycles. They concluded that the Graz cycle, in the original version including the second bottoming cycles, is expected to be able to deliver around 3\% points' net efficiency benefit over the semiclosed oxyfuel combustion combined cycle at the expense of a more complex realization of the cycle.

Comparative work on the two cycles has suffered from not having the same technology level in the design of the two cycles. This results in the fact that it is difficult to draw conclusions from the comparisons. The aim of the current study is to assess the two cycles using the same technology level and in addition have comparable complexity levels. The current study goes into more details regarding the optimal pressure ratio and turbine entry temperatures for the oxyfuel combustion cycles then past publications. This is accomplished by establishing a reference cycle, which has a technology level that could enter service around year 2025. The fuel is assumed to be natural gas for all three cycles. The reference cycle is then used as the starting point for the modelling of the oxyfuel combustion combined cycles. In the current study the pressure ratio has been varied to locate the optimal net efficiency with respect to pressure ratio. Previous work has reported around 3\% points' benefit for the Graz cycle [32] including work carried out by the authors [35]. It was viewed that a majority of these benefits would be attributed to the use of a second bottoming cycle as included in the original implementation. To make a fair comparison of the two alternatives it was decided to exclude this cycle feature from the original Graz cycle. It should be noted that it is quite feasible to introduce such a bottoming concept also for the SCOC$\mathrm{CC}$ if the target would be to achieve maximum efficiency. The two simpler implementations were preferred in order to keep down complexity and make practical implementation more feasible.

\section{Methods}

The heat and mass balance program IPSEpro is used to simulate the power cycles [38]. The systems of equations, which are established using a graphical interface, are solved using a Newton-Raphson based algorithm. The simulation program was modified to incorporate the thermodynamic and transport properties program REFPROP to calculate the physical properties of fluids [39].

\subsection{Cooled Turbine}

2.1.1. Cooling Model. The cooling model is very important when studying the performance of gas turbine based cycles. The cooling model used is the $m^{*}$ model and is based on 
the work of Halls [40] and Holland and Thake [41]. The model is based on the standard blade assumption, which assumes that the blade has infinite thermal conductivity and a uniform blade temperature. The model used in this study was originally implemented by Jordal [42].

The main parameters for the cooling model are first the cooling efficiency

$$
\eta_{c}=\frac{T_{\mathrm{ce}}-T_{\mathrm{ci}}}{T_{\mathrm{bu}}-T_{\mathrm{ci}}}
$$

where $T_{\mathrm{ci}}$ is the temperature of the cooling flow at the inlet, $T_{\text {ce }}$ is the temperature of the cooling flow at the exit, and $T_{\text {bu }}$ is the uniform blade temperature. The cooling efficiency is set to a moderate limit of $\eta_{c}=0.50$.

Second the cooling effectiveness is defined as

$$
\varepsilon_{c}=\frac{T_{g}-T_{\mathrm{bu}}}{T_{g}-T_{\mathrm{ci}}},
$$

where $T_{g}$ is the hot gas temperature.

The model is a first-law thermodynamic, nondimensional model. The model is based on the dimensionless mass flow cooling

$$
\dot{m}^{*}=\frac{\dot{m}_{c} C_{p, c}}{\overline{\alpha_{g}} A_{b}}
$$

where $\dot{m}_{c}$ is the cooling mass flow, $C_{p, c}$ is the heat capacity of the cooling fluid, $\alpha_{g}$ is the convective heat transfer coefficient on the hot gas side, and $A_{b}$ is the area of the blade. The main parameter of interest is the coolant mass flow ratio

$$
\varphi=\frac{\dot{m}_{c}}{\dot{m}_{g}}=\dot{m}^{*} \frac{C_{p, g}}{C_{p, \mathrm{ci}}} \mathrm{St}_{g} \frac{A_{b}}{A_{g}},
$$

where $C_{p, g}$ is the heat capacity of the hot gas, $\mathrm{St}_{g}$ is the average Stanton number of the hot gas, and $A_{g}$ is the cross-sectional area of the hot gas. The relations between the cooling mass flow and the temperature differences are

$$
\frac{\dot{m}_{c} C_{p, \mathrm{ci}}}{\overline{\alpha_{g}} A_{b}}=\frac{T_{g}-T_{\mathrm{bu}}}{T_{\mathrm{bu}}-T_{\mathrm{ci}}} .
$$

The Stanton number is defined as

$$
\mathrm{St}_{g}=\frac{\alpha_{g}}{\rho_{g} U_{g} C_{p, g}}
$$

where $\rho_{g}$ is the density of the hot gas and $U_{g}$ is the flow velocity.

To estimate the cooling requirements for each cooled turbine blade row, it was assumed that the cooling parameters were constant. The parameters were chosen to represent a cooled turbine that will enter service around 2025.

The uniform blade metal temperature is set to $850^{\circ} \mathrm{C}$. This means that the maximum temperature will be around $950^{\circ} \mathrm{C}$ and the average temperature at the gas side of the blade around $900^{\circ} \mathrm{C}$. The uniform blade metal temperature is used as the temperature limit for the cycle simulations.
TABLE 3: Parameters assumed in the cooling model.

\begin{tabular}{lc}
\hline$T_{\mathrm{bu}}$ & $850^{\circ} \mathrm{C}$ \\
$\mathrm{St}_{g}$ & 0.005 \\
$A_{b} / A_{g}$ & 5 \\
$\eta_{c}$ & 0.50 \\
$S$ & 0.2 \\
\hline
\end{tabular}

It is assumed, as has been done in other studies [11, 4346], that the Stanton number is constant, $\mathrm{St}=0.005$, in regard to both the change in the working fluid and the change in the design parameters. The parameters that are assumed to be constant in the cooling model are shown in Table 3 . The geometry parameter, $A_{b} / A_{g}$, which is the ratio between the wetted blade and adjacent cooled surface areas over the average gas cross-sectional area, is also held constant between all cases. This parameter is unknown for a thermodynamic analysis where the key dimensions of the turbine have not been designed. El-Masri [44] estimated that this parameter is slightly less than 4.0 for a cascade blade row and around 8.0 for a stage, allowing for a row-to-row spacing. Jordal [47] concluded that when taking into account that rotor disks and the transition piece from the combustion chamber to the first stage nozzles are also subject to cooling, an average value should be around 5.0 for a stage.

The cooling model was used to reproduce the results in [48] and showed good agreement.

2.1.2. Expansion. The expansion in an uncooled turbine is modelled as

$$
\eta_{p}=\frac{\left(s_{2}-s_{1}\right)+R \ln \left(p_{2} / p_{1}\right)}{R \ln \left(p_{2} / p_{1}\right)},
$$

where $R$ is the gas constant for the working fluid, $p, s$ are the pressure and entropy, respectively, 1 is the inlet, and 2 is the outlet of the turbine stage. This model was evaluated against different models such as Mallen and Saville [49], using numerical integration and the model used gave good agreement with the numerical integration.

For the cooled turbine, the mixing of the coolant and the main stream gas flow result in a loss in stagnation pressure. This irreversibility is taken into account by defining a new polytropic efficiency $[42,50]$, defined as

$$
\eta_{\mathrm{pr}}=\eta_{p}-S \ln \left(\frac{p_{\text {in }}}{p_{\text {out }}}\right) \frac{p_{1}}{p_{\text {in }}-p_{\text {out }}} \frac{\dot{m}_{g, \text { out }}-\dot{m}_{g, \text { in }}}{\dot{m}_{g, \text { in }}},
$$

where $p_{1}$ is the stagnation pressure at the inlet of the rotor blade row, in is the inlet to the turbine, and out is the outlet of the turbine. Parameter $S$ is specific to each turbine and models the losses. It is typically in the range of 0.1 for a turbine that has good performance and around 0.5 for a turbine that has poor performance [51]. The polytropic efficiency is set to $\eta_{p}=$ $90 \%$. The losses are taken into account by assuming that the factor is $S=0.2$ for all cases. Dahlquist et al. examined the empirical loss models used to design turbomachinery, which are generated using air as the working fluid, and concluded 
that the loss models generate similar results for the working fluids in oxyfuel cycles [52]. This indicates that it is possible to achieve a similar technology level for the oxyfuel turbines as for state-of-the-art conventional turbines.

2.2. Compressor. The compression is modelled using polytropic efficiency,

$$
\eta_{p}=\frac{R \ln \left(p_{2} / p_{1}\right)}{\left(s_{2}-s_{1}\right)+R \ln \left(p_{2} / p_{1}\right)},
$$

where $R$ is the gas constant for the working fluid, $p$ and $s$ are the pressure and entropy, respectively, 1 is the inlet, and 2 is the outlet of the compressor.

It is assumed that the polytropic efficiency is constant for all cycles and all cases and is assumed to be $\eta_{p}=91 \%$. Similar to the turbine, it is assumed that it is possible to achieve a compressor design for the oxyfuel compressor that is on the same level as the state of the art of compressors in conventional gas turbines.

2.3. Combustor. The combustion is a simple energy model based on the assumption that all of the fuel is completed in the combustion, that is, $100 \%$ combustion efficiency.

The amount of excess $\mathrm{O}_{2}$ is calculated as

$$
\lambda=\frac{\dot{m}_{\mathrm{O}_{2}, \text { in }}}{\dot{m}_{\mathrm{O}_{2}, \text { in }}-\dot{m}_{\mathrm{O}_{2}, \text { out }}},
$$

where $\lambda=1.0$ is stoichiometric combustion. For the oxyfuel cycles the combustion is nearly stoichiometric; that is $\lambda=$ 1.01. It is preferred that the combustion takes place as close to stoichiometric conditions as possible to reduce the amount of $\mathrm{O}_{2}$ that the ASU needs to produce. Such a low amount of excess $\mathrm{O}_{2}$ is very different compared to traditional combustion in gas turbines, which have much larger amount of excess $\mathrm{O}_{2}$. It is assumed that it is possible to have the combustion under near stoichiometric conditions while the emissions of $\mathrm{NO}_{x}, \mathrm{CO}$ and unburned hydrocarbons are within given constraints. Sundkvist et al. found that using excess of $0.5 \%$ of $\mathrm{O}_{2}, \lambda=1.005$, resulted in $400 \mathrm{ppmv}$ of $\mathrm{CO}$ at the turbine outlet [53] and increasing the $\mathrm{O}_{2}$ ratio resulted in reduced levels of $\mathrm{CO}$, while increasing the energy penalty from the ASU, as expected.

The pressure drop in the combustion chamber is assumed to be $4 \%$. And a compressor is used to increase the pressure of the fuel above the pressure in the combustion chamber.

2.4. Air Separation Unit. $\mathrm{O}_{2}$ is produced with an air separation unit (ASU). The ASU is assumed to be a cryogenic air separation plant. Modelling of the ASU is not within the scope of this current study. ASU power consumption is highly dependent on the purity of the $\mathrm{O}_{2}$ stream. It is therefore an economic trade-off between purity and cost. Typical state-ofthe-art cryogenic ASU can produce $\mathrm{O}_{2}$ with $99.5 \%$-volume purity at a power consumption of $900 \mathrm{~kW} /(\mathrm{kg} / \mathrm{s})$ [54]. By decreasing the purity, it is possible to reduce the power consumption of the ASU. At a purity level of $95 \%$, the power
TABLE 4: Oxygen composition.

\begin{tabular}{lc}
\hline & Mass fraction \\
\hline $\mathrm{Ar}$ & $3.0 \%$ \\
$\mathrm{~N}_{2}$ & $2.0 \%$ \\
$\mathrm{O}_{2}$ & $95.0 \%$ \\
\hline
\end{tabular}

consumption can be assumed to be around $735 \mathrm{~kW} /(\mathrm{kg} / \mathrm{s})$ $[17,55]$. In this study this has been taken into account and a purity level of $95 \%$ for the ASU is used. The corresponding $\mathrm{O}_{2}$ composition is shown in Table 4 .

The ASU unit delivers the $\mathrm{O}_{2}$ stream at a pressure of 1.2 bar and with a temperature of $30^{\circ} \mathrm{C}$. An intercooled compressor is used to increase the pressure of the stream to the working pressure in the combustor. The compression process has been modelled in the cycle simulation.

2.5. Flue Gas Condenser. The main purpose of the oxyfuel combustion cycles is to produce $\mathrm{CO}_{2}$ along with power generation. Because the flue gas consists mostly of $\mathrm{CO}_{2}$ and steam, the most convenient method is to condense the water from the flue gas to produce the $\mathrm{CO}_{2}$. The flue gas will also contain small amounts of $\mathrm{Ar}, \mathrm{N}_{2}$, and $\mathrm{O}_{2}$. There will also be traces of harmful acid gases along with particles such as soot. By using a direct contact condenser, these harmful gases and the particles can be removed from the flue gas when the steam is condensed. The condenser will therefore also act as a scrubber.

The efficiency of the condenser is defined as

$$
\eta_{\text {condenser }}=\frac{\dot{m}_{\text {condense }}}{\dot{m}_{\mathrm{H}_{2} \mathrm{O} \text {,in }}}
$$

where $\dot{m}_{\text {condense }}$ is the amount of water that is condensed from the flue gas and $\dot{m}_{\mathrm{H}_{2} \mathrm{O} \text {,in }}$ is the amount of water in the flue gas that enters the condenser. The flue gas condenser efficiency is a simple way to evaluate the performance of the condensers [56]. The parameter does not represent an efficiency in its true sense but is a metric commonly used to describe the performance of condensers [56].

2.6. $\mathrm{CO}_{2}$ Compression. The $\mathrm{CO}_{2}$ stream from the condenser that will be sent to storage needs to be compressed to a higher pressure and the remaining water vapour and noncondensable gases need to be removed. This process, the $\mathrm{CO}_{2}$ recovery and compression process, is not within the system boundaries of the current study. It is instead taken into account by assuming a fixed energy cost, $350 \mathrm{~kW} /(\mathrm{kg} / \mathrm{s})$ of wet $\mathrm{CO}_{2}$ [25]. This energy cost assumes that the stream is compressed to 100 bar. This value also takes into account the removal of water and other gases that are present in the $\mathrm{CO}_{2}$ stream.

\section{Power Cycles}

The fuel is assumed to be natural gas and the composition is shown in Table 5. Common assumptions used in the simulations of the cycles are shown in Table 6. 
TABLE 5: Natural gas fuel composition.

\begin{tabular}{lc}
\hline & Mass fraction \\
\hline $\mathrm{CH}_{4}$ & $84.7 \%$ \\
$\mathrm{~N}_{2}$ & $3.3 \%$ \\
$\mathrm{CO}_{2}$ & $2.5 \%$ \\
$\mathrm{C}_{2} \mathrm{H}_{6}$ & $7.0 \%$ \\
$\mathrm{C}_{3} \mathrm{H}_{8}$ & $2.6 \%$ \\
\hline
\end{tabular}

3.1. Reference Cycle. A reference cycle was modelled that is in the mid-size range. The mid-size range is from 30 to $150 \mathrm{MW}$ [42]. Here we have aimed at keeping the gross combined power output from the gas turbine and the steam turbine constant at $100 \mathrm{MW}$. The reference cycle has been modelled as a gas generator and a separate power turbine, that is, a twoshaft gas turbine. The gas generator turbine consists of two cooled stages. The cooling flow is bled from the compressor. The steam cycle for a power plant in this power range usually employs single or double pressure levels and does not use reheat. Here we have used a dual-pressure steam cycle without reheat. The steam turbine is a single-casing nonreheat. The pressure was set to 140 bar and the maximum temperature to $560^{\circ} \mathrm{C}$ at the inlet to the steam turbine. If the exhaust temperature from the gas turbine goes below $585^{\circ} \mathrm{C}$ the steam temperature decreases so that the temperature difference is $25^{\circ} \mathrm{C}$. A schematic of the cycle is shown in Figure 1.

3.2. SCOC-CC. A schematic of the SCOC-CC is shown in Figure 2. The SCOC-CC is based on the reference cycle. Now, however, the fuel is combusted with $\mathrm{O}_{2}$ that is produced in the ASU. The fuel is combusted near to stoichiometric ratio, meaning that nearly no excess $\mathrm{O}_{2}$ is produced. This minimizes the power demand of the ASU. The combustion chamber is cooled using the recycled flue gas, after most of the steam is condensed from it, in the condenser. The flue gas leaving the combustion chamber is mainly $\mathrm{CO}_{2}$ and also a small amount of steam. The gas turbine layout is the same as the reference cycle with a gas generator and a power turbine. The turbine in the gas generator has two stages, which are both cooled. The cooling flow is also bled from the compressor, similar to the reference cycle. The layout of the steam cycle is unchanged from the reference cycle. The flue gas goes to the condenser after the heat recovery steam generator, where the major part of the steam is condensed from the exhaust gas. The flue gas is cooled in this process. The $\mathrm{CO}_{2}$ stream that leaves the condenser has near $100 \%$ relative humidity. A small part of the $\mathrm{CO}_{2}$ stream is sent to the compression and purification process and is then transferred to the storage site. The major part of the $\mathrm{CO}_{2}$ is recycled back to the compressor. The water in the $\mathrm{CO}_{2}$ stream can possibly condense at the entry to the compressor, which could have a deteriorating effect for the compressor. The $\mathrm{CO}_{2}$ stream is therefore heated before it enters the compressor using the heat from the flue condensation.

3.3. Graz Cycle. The main features are that the gas turbine cooling is implemented with steam and that the flue gas is sent
TABLE 6: Assumptions used in cycle simulations.

\begin{tabular}{|c|c|}
\hline Compressor polytropic efficiency & 0.91 \\
\hline Compressor mechanical efficiency & 0.99 \\
\hline Combustor pressure drop & $4 \%$ \\
\hline Turbine polytropic efficiency & 0.90 \\
\hline Power turbine polytropic efficiency & 0.89 \\
\hline Gas turbine mechanical efficiency & 0.99 \\
\hline Generator electricity efficiency & 0.985 \\
\hline Generator mechanical efficiency & 0.994 \\
\hline Lower heating value for fuel & $46885 \mathrm{~kJ} / \mathrm{kg}$ \\
\hline Fuel temperature & $15^{\circ} \mathrm{C}$ \\
\hline Fuel compressor isentropic efficiency & 0.80 \\
\hline Ambient temperature & $15^{\circ} \mathrm{C}$ \\
\hline Ambient pressure & $1.013 \mathrm{bar}$ \\
\hline Ambient humidity & $60 \%$ \\
\hline Condenser pressure & 0.045 bar \\
\hline HRSG heat exchangers $\Delta p$, hot side & $0.001 \mathrm{bar}$ \\
\hline HRSG heat exchangers $\Delta p$, cold side & $0.9 \mathrm{bar}$ \\
\hline Steam turbine isentropic efficiency & 0.89 \\
\hline Superheater, LP, $\Delta T_{\text {pinch }}$ & $10 \mathrm{~K}$ \\
\hline Superheater, HP, minimum $\Delta T_{\text {pinch }}$ & $25 \mathrm{~K}$ \\
\hline Evaporator $\Delta T_{\text {pinch }}$ & $10 \mathrm{~K}$ \\
\hline HP steam pressure & 140 bar \\
\hline HP steam maximum temperature & $560^{\circ} \mathrm{C}$ \\
\hline LP steam pressure & 7 bar \\
\hline Pump efficiency & 0.7 \\
\hline Pump mechanical efficiency & 0.9 \\
\hline Deaerator operating pressure & $1.21 \mathrm{bar}$ \\
\hline Deaerator saturation temperature & $105^{\circ} \mathrm{C}$ \\
\hline ASU power consumption & $735 \mathrm{~kW} /(\mathrm{kg} / \mathrm{s})$ \\
\hline $\mathrm{O}_{2}$ purity & $95 \%$ \\
\hline $\mathrm{O}_{2}$ compressor polytropic efficiency & 0.88 \\
\hline ASU delivery pressure & $1.2 \mathrm{bar}$ \\
\hline ASU delivery temperature & $30^{\circ} \mathrm{C}$ \\
\hline Carbon dioxide compression power & $350 \mathrm{~kW} /(\mathrm{kg} / \mathrm{s})$ \\
\hline Condenser efficiency, maximum & 0.85 \\
\hline Gross power output & $100 \mathrm{MW}$ \\
\hline
\end{tabular}

straight to the compressor after the HRSG without condensing the steam from it. Part of the flue gas is sent to a condenser where a major part of the water is condensed from it; after this it is sent to the $\mathrm{CO}_{2}$ compression and purification process. The $\mathrm{CO}_{2}$ is afterwards transferred to the storage site.

The most common layout of the Graz cycle incorporates two bottoming cycles. The first one uses a typical HRSG and a steam turbine, which only expands, however, to the pressure of the combustion chamber. This is because the steam is used for cooling both the combustion chamber and the gas turbine blades. The second bottoming cycle uses the enthalpy of the condensation and assumes that the pressure at the outlet of the condenser is 0.021 bar, which is particularly low. 


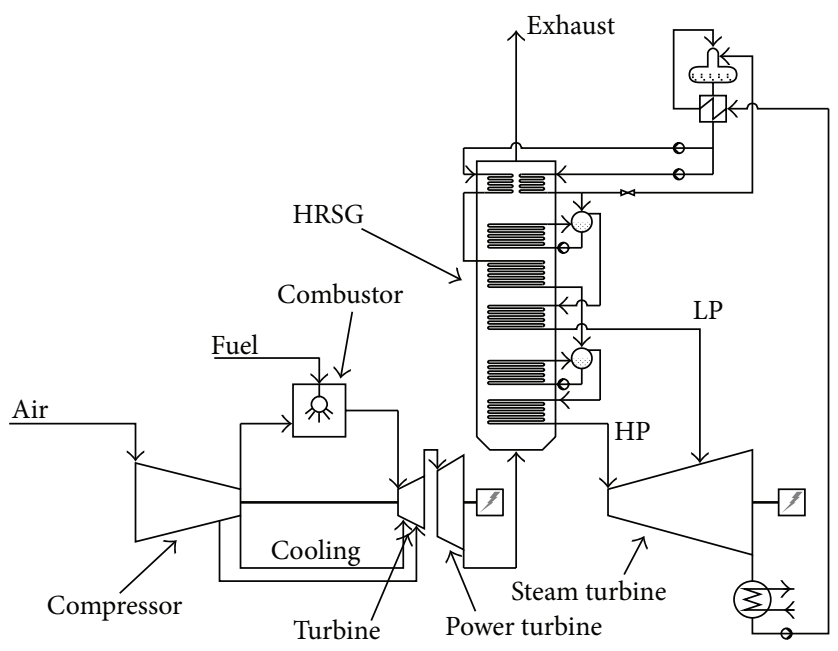

FIgURE 1: Schematic layout of the reference cycle.

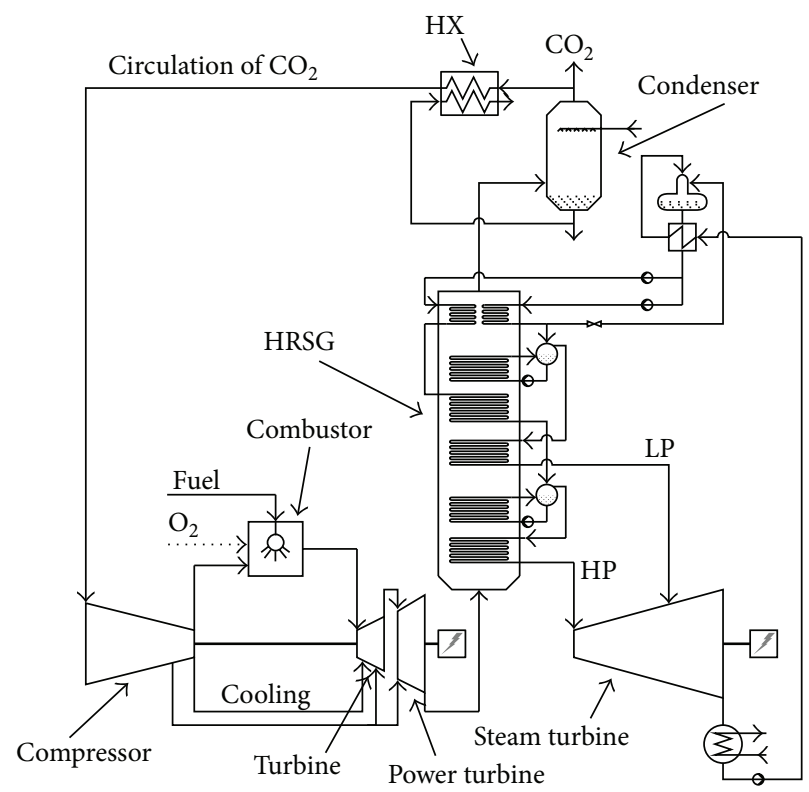

FIGURE 2: Schematic layout of the SCOC-CC.

It is hard to imagine that the first design of the Graz cycle will deviate so greatly from the current layout of the combined cycle. Here we have taken the reference cycle as the basis and implemented the major design features of the Graz cycle. A schematic of the Graz cycle is shown in Figure 3. The cycle incorporates an intercooler to reduce the temperature of the gas at the exit of the compressor as well as steam cooling. This layout, not implementing the second bottoming cycle, is considered more reasonable for the first generation design of the cycle. It also makes the complexity level of the SCOCC$\mathrm{CC}$ and the Graz cycle more comparable, by not including improvements that could be implemented on both cycles.

The cycle illustrated in Figure 3 should therefore be understood as a simplified variant of the Graz cycle.

\section{Results}

A parametric study of the two oxyfuel cycles was performed by varying the turbine entry temperature (TET) and the pressure ratio $(\mathrm{PR})$ of the gas turbine. The turbine entry temperature is the temperature at the exit of the combustion chamber and is therefore also the temperature at the entry to the first stator in the gas turbine. The temperature has been varied from $1250^{\circ} \mathrm{C}$ to $1600^{\circ} \mathrm{C}$. The pressure ratio was varied freely until the design constraints were attained.

4.1. Reference Cycle. The results for the cycle net efficiency are shown in Figure 4 as a function of pressure ratio. The turbine entry temperature is also shown in Figure 4 . The net efficiency 


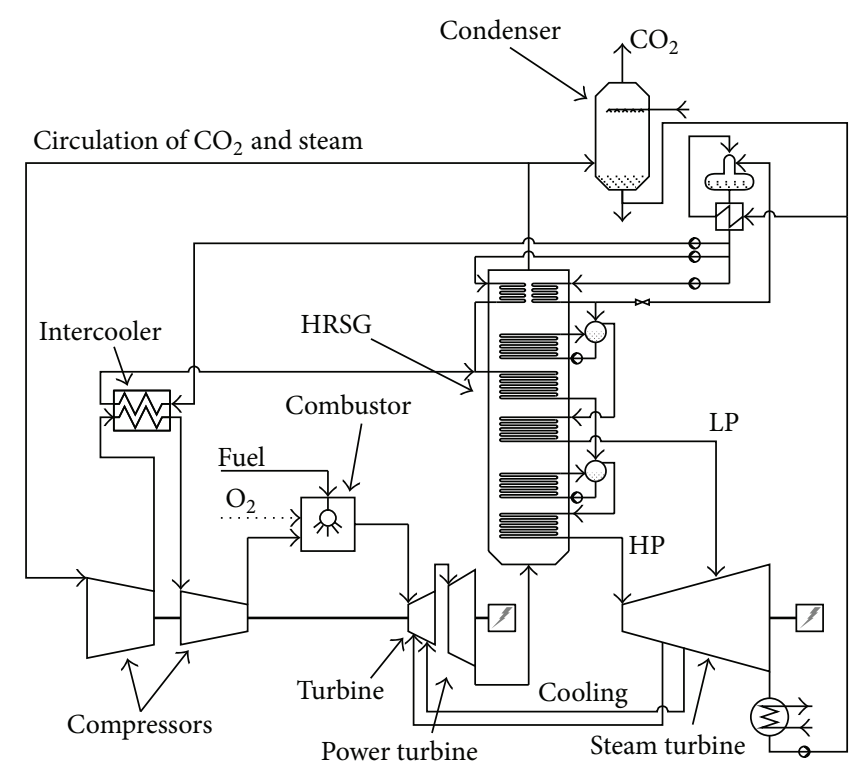

FIGURE 3: Schematic layout of the Graz cycle.

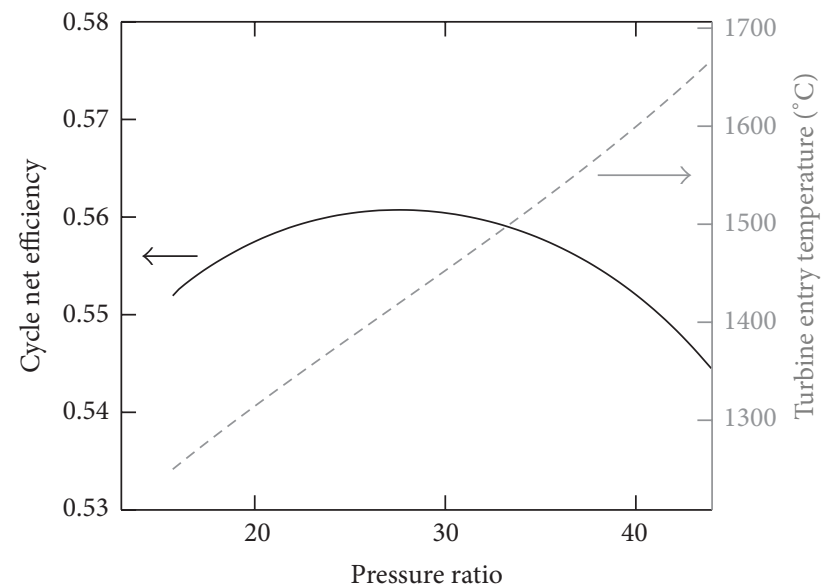

FIGURE 4: Net efficiency and turbine entry temperature as functions of pressure ratio for the reference cycle.

takes into account the power needed for the pumps in the cycle. The entry temperature for the power turbine has been set to $850^{\circ} \mathrm{C}$, to eliminate the need for cooling in the power turbine. If the temperature goes above $850^{\circ} \mathrm{C}$, which is the metal temperature limit for the blades, then the first stage in the power turbine would then need to be cooled.

Figure 5 shows the cooling mass flow ratio for the reference cycle. The ratio is defined as the total cooling mass flow divided by the inlet mass flow to the turbine.

4.2. SCOC-CC. Figure 6 shows the gross efficiency for the SCOC-CC as a function of pressure ratio and turbine entry temperature. The gross efficiency is the total power delivered by the gas turbine and steam turbine generators divided by the energy content of the fuel, based on the lower heating value.

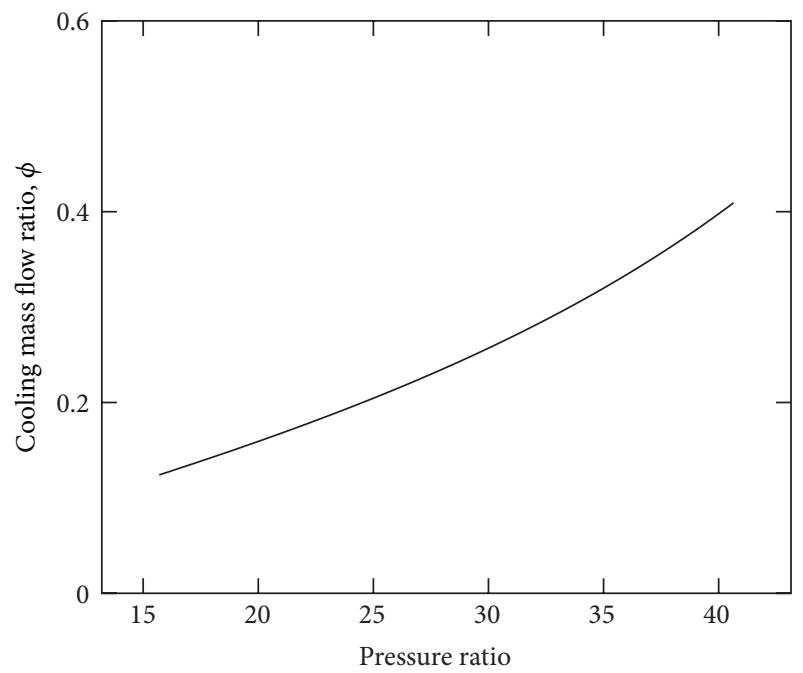

FIGURE 5: Cooling mass flow ratio as function of pressure ratio for the reference cycle.

As the pressure ratio decreases, the amount of steam in the low pressure steam is also reduced. The lower limit for the pressure ratio is reached when the mass flow of the low pressure steam approaches zero. The higher pressure ratio limit is reached when the temperature difference for the high pressure steam and the flue gas in the preheater approaches $5^{\circ} \mathrm{C}$.

Figure 7 shows the net efficiency for the SCOC-CC as a function of pressure ratio and turbine entry temperature. The net efficiency takes into account the fuel compressor power, the power needed for the pumps, the energy needed for the production of the $\mathrm{O}_{2}$, the $\mathrm{O}_{2}$ compressor power, and the power needed to compress the $\mathrm{CO}_{2}$. The largest decrease in the efficiency comes from the power requirement for the $\mathrm{O}_{2}$ production and compression. As the pressure ratio is 


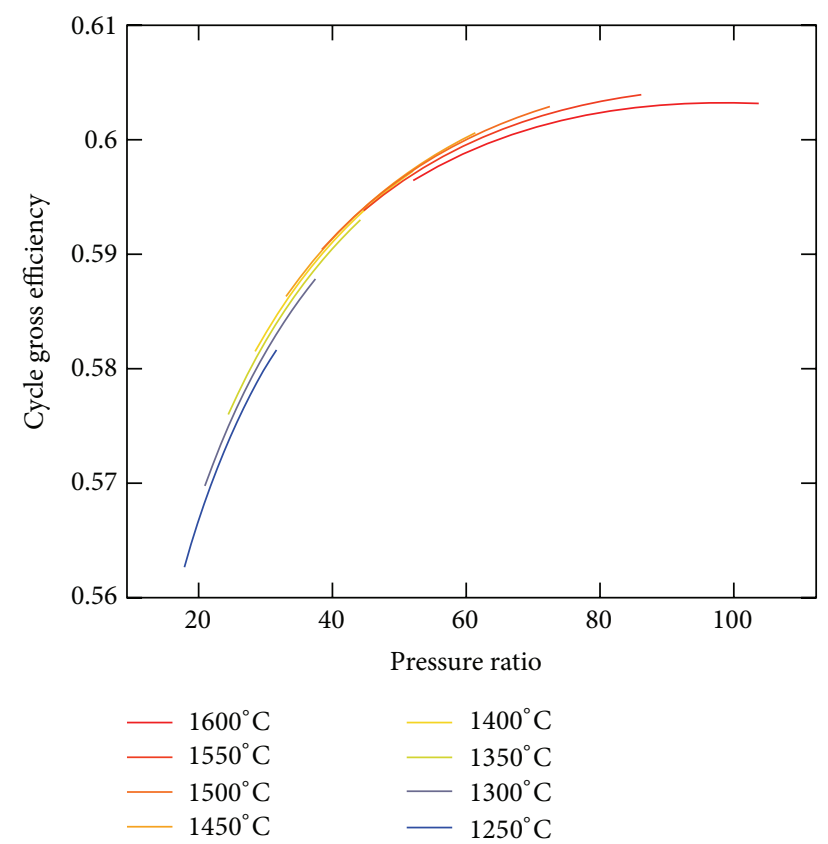

FIGURE 6: Gross efficiency as function of pressure ratio and turbine entry temperature for the SCOC-CC.

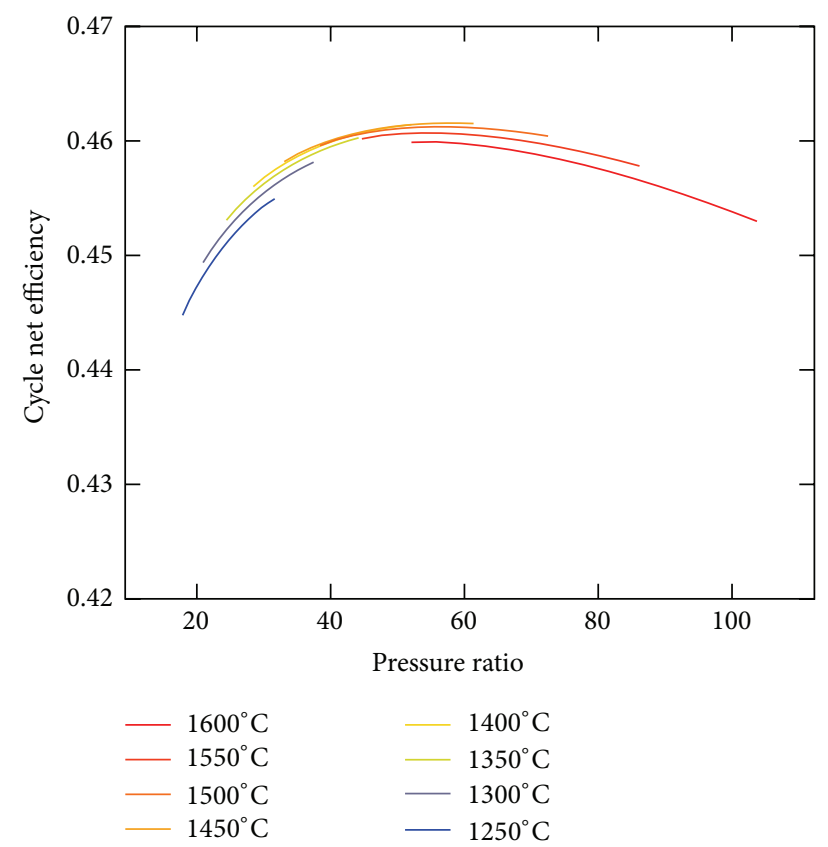

FIGURE 7: Net efficiency as function of pressure ratio and turbine entry temperature for the SCOC-CC.

increased, the $\mathrm{O}_{2}$ compression power consumption increases very rapidly. This results in there being an optimum pressure ratio.

Figure 8 shows the power entry temperature as a function of pressure ratio and turbine entry temperature for the SCOC-CC. As can be seen in Figure 8 the power turbine entry

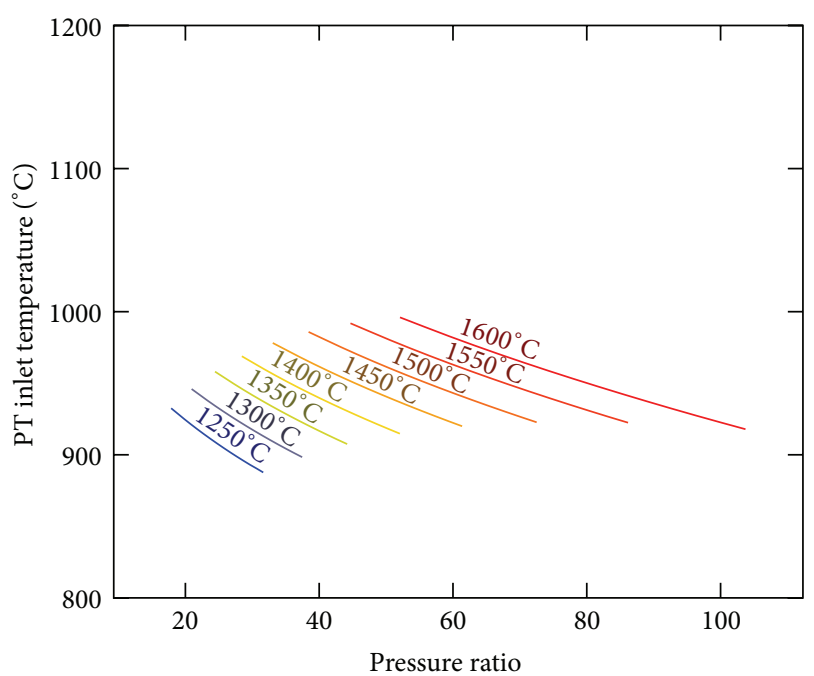

Figure 8: Power turbine entry temperature as function of pressure ratio and turbine entry temperature for the SCOC-CC.

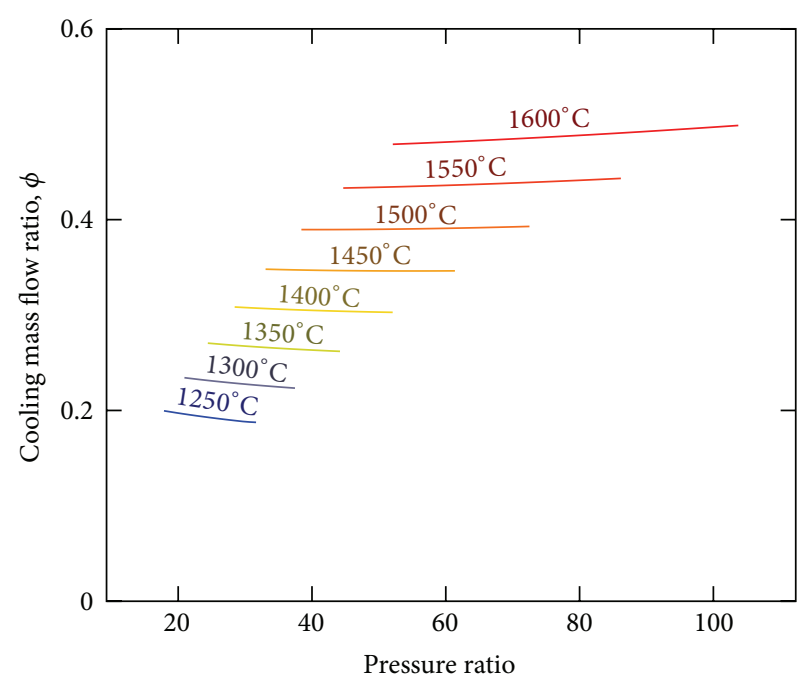

FIGURE 9: Cooling mass flow ratio as function of pressure ratio and the turbine entry temperature for the SCOC-CC.

temperature for all cases is above the blade material temperature limit, $850^{\circ} \mathrm{C}$. This means that the first stage in the power turbine needs to be cooled.

Figure 9 shows the cooling mass flow ratio as a function of pressure ratio and turbine entry temperature for the SCOCCC. The cooling mass flow ratio is higher for the SCOC-CC than the reference cycle, since the heat capacity for the working fluid is lower in the SCOC-CC than in the reference cycle.

4.3. Graz Cycle. The Graz cycle was studied at turbine entry temperatures of $1250^{\circ} \mathrm{C}, 1450^{\circ} \mathrm{C}$, and $1600^{\circ} \mathrm{C}$. Figure 10 shows the gross efficiency for the Graz cycle as a function of pressure ratio and turbine entry temperature. It can be seen in Figure 10 that there is no global optimum for the gross efficiency. 


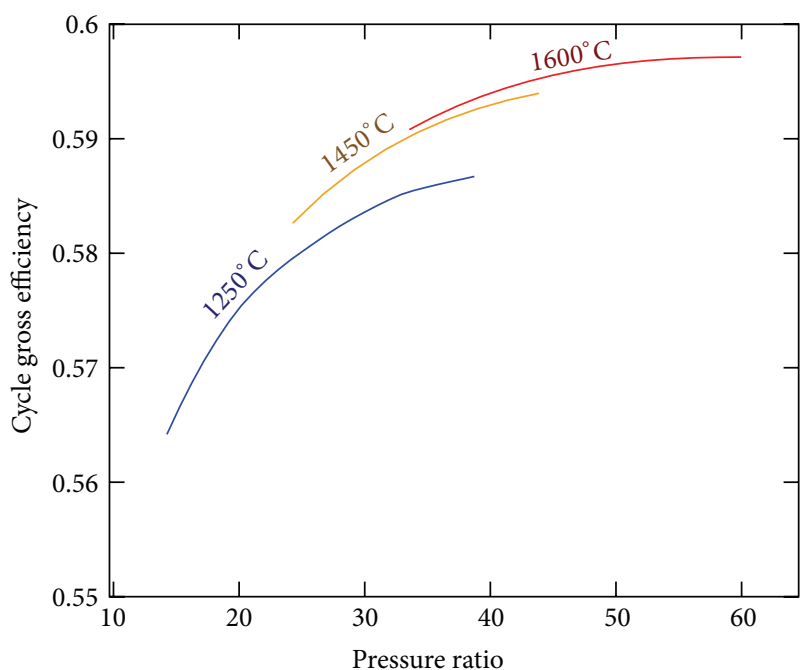

Figure 10: Gross efficiency as function of pressure ratio and turbine entry temperature for the Graz cycle.

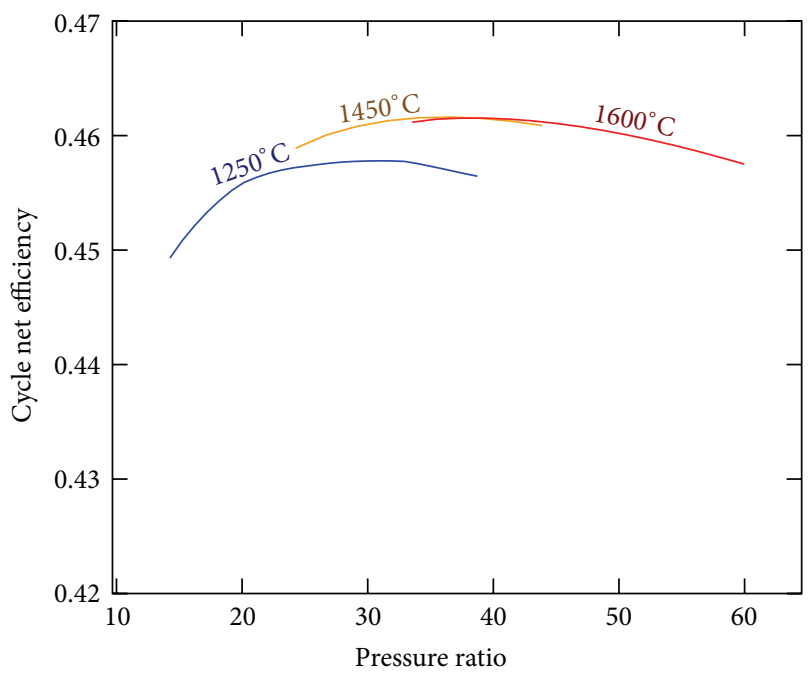

FIGURE 11: Net efficiency as function of pressure ratio and turbine entry temperature for the Graz cycle.

Figure 11 shows the net efficiency for the Graz cycle as a function of pressure ratio and turbine entry temperature. The net efficiency is calculated as is done for the SCOC-CC. The major reduction in the efficiency comes from the power needed for the $\mathrm{O}_{2}$ production and compression. The relative power consumption of the $\mathrm{O}_{2}$ compression increases as the pressure ratio increases, which results in an optimum in the net efficiency. Figure 12 shows the power entry temperature as a function of pressure ratio and turbine entry temperature for the Graz cycle. When the power turbine entry temperature is over $850^{\circ} \mathrm{C}$, the first stage in the power turbine is cooled.

Figure 13 shows the cooling mass flow ratio as a function of pressure ratio and turbine entry temperature for the Graz cycle. Since steam is used as coolant for the turbine blade

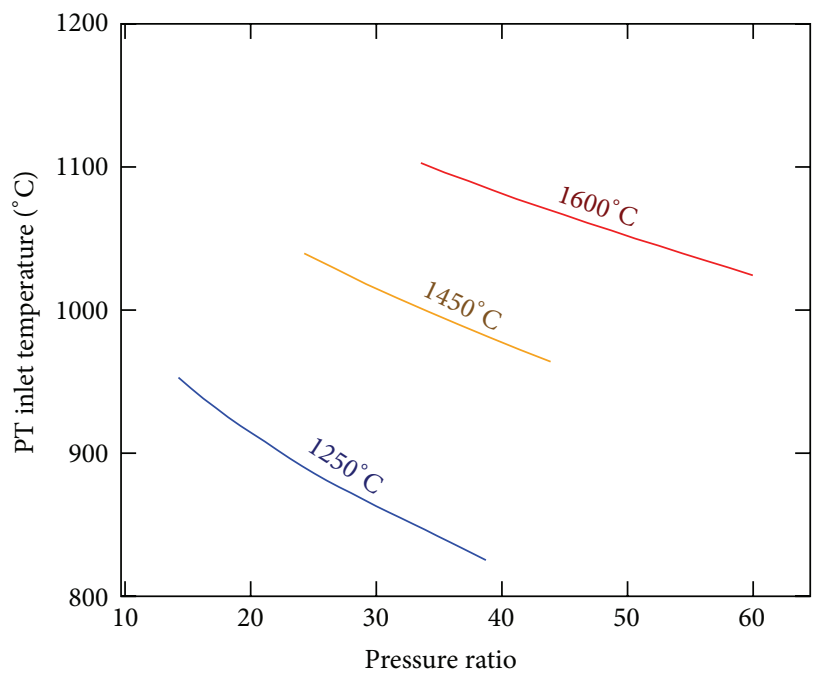

FIGURE 12: Power turbine entry temperature as function of pressure ratio and turbine entry temperature for the Graz cycle.

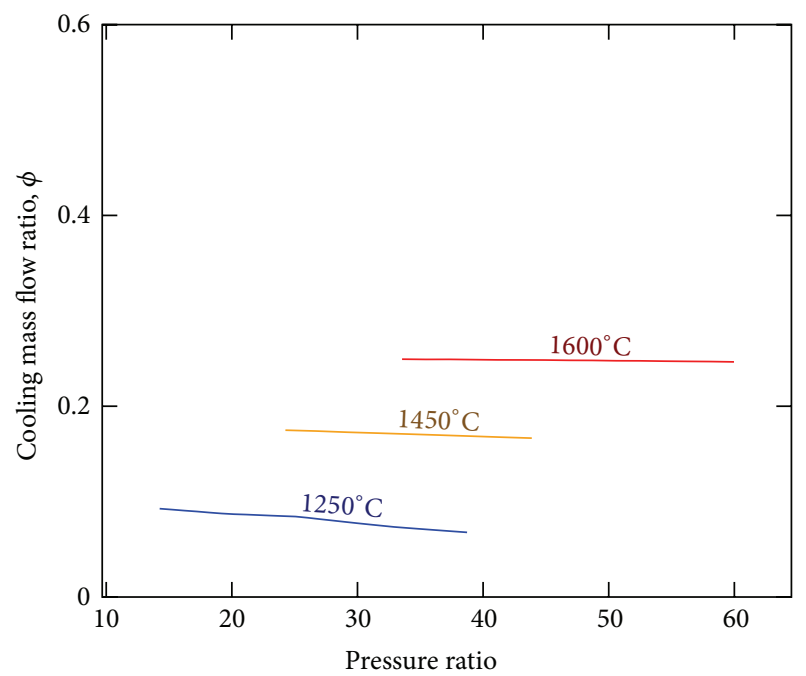

FIGURE 13: Cooling mass flow ratio as function of pressure ratio and the turbine entry temperature for the Graz cycle.

cooling for the Graz cycle, the cooling mass flow ratio is considerably lower than for the reference cycle and the SCOCCC. This is the result of the fact that the steam has a substantially lower temperature than the compressor discharge temperature and that the steam has a higher heat capacity than the working fluid.

4.4. Optimum Cycles. The results for the cycles with the optimum performance are shown in Table 7. The optimum reference cycle is determined to be a cycle where there is no need to employ cooling for the power turbine. This means that the power turbine entry temperature is $850^{\circ} \mathrm{C}$ or lower. The pressure ratio that gives the optimal efficiency is 26.15 and the turbine entry temperature is $1400^{\circ} \mathrm{C}$, which results in a net efficiency of $56 \%$. The turbine exhaust temperature is only $526^{\circ} \mathrm{C}$, 
TABLE 7: Results for the optimal cycles.

\begin{tabular}{|c|c|c|c|c|}
\hline & & Reference & SCOC-CC & Graz \\
\hline Heat input & MW & 176 & 167 & 169 \\
\hline GT power output & MW & 69 & 62 & 76 \\
\hline GT efficiency & $\%$ & 39.48 & 37.08 & 45.18 \\
\hline ST power output & MW & 31 & 38 & 24 \\
\hline ST efficiency & $\%$ & 17.35 & 22.86 & 14.00 \\
\hline Gross power output & MW & 100 & 100 & 100 \\
\hline $\mathrm{O}_{2}$ production & MW & & 10.3 & 10.4 \\
\hline $\mathrm{O}_{2}$ compression & MW & & 6.91 & 5.98 \\
\hline $\mathrm{CO}_{2}$ compression & MW & & 3.60 & 3.79 \\
\hline Net power output & MW & 98.6 & 77.0 & 78.0 \\
\hline Gross efficiency & $\%$ & 56.83 & 59.94 & 59.18 \\
\hline Net efficiency & $\%$ & 56.04 & 46.16 & 46.16 \\
\hline Compressor pressure ratio & & 26.2 & 57.3 & 36.5 \\
\hline Compressor outlet temp & ${ }^{\circ} \mathrm{C}$ & 507 & 474 & 605 \\
\hline Compressor mass flow at inlet & $\mathrm{kg} / \mathrm{s}$ & 181 & 149 & 73 \\
\hline Cooling mass flow ratio & & 0.22 & 0.35 & 0.17 \\
\hline TET $^{*}$ & ${ }^{\circ} \mathrm{C}$ & 1400 & 1450 & 1450 \\
\hline $\mathrm{TIT}^{\dagger}$ & ${ }^{\circ} \mathrm{C}$ & 1251 & 1208 & 1274 \\
\hline Power TET & ${ }^{\circ} \mathrm{C}$ & 850 & 927 & 998 \\
\hline Exhaust gas flow & $\mathrm{kg} / \mathrm{s}$ & 185 & 166 & 106 \\
\hline Exhaust temperature & ${ }^{\circ} \mathrm{C}$ & 526 & 618 & 614 \\
\hline Stack temperature & ${ }^{\circ} \mathrm{C}$ & 96 & 65 & 100 \\
\hline LP steam pressure & bar & 7 & 7 & 7 \\
\hline LP steam temperature & ${ }^{\circ} \mathrm{C}$ & 337 & 337 & 337 \\
\hline LP steam mass & $\mathrm{kg} / \mathrm{s}$ & 7 & 3 & 3 \\
\hline HP steam pressure & bar & 140 & 140 & 140 \\
\hline HP steam temperature & ${ }^{\circ} \mathrm{C}$ & 501 & 560 & 560 \\
\hline HP steam mass & $\mathrm{kg} / \mathrm{s}$ & 21 & 27 & 26 \\
\hline $\mathrm{O}_{2}$ mass flow & $\mathrm{kg} / \mathrm{s}$ & & 14.0 & 14.2 \\
\hline $\mathrm{CO}_{2}$ mass flow & $\mathrm{kg} / \mathrm{s}$ & & 10.3 & 10.8 \\
\hline
\end{tabular}

${ }^{*}$ Same as combustor outlet temperature (COT).

${ }^{\dagger}$ Turbine inlet temperature based on the ISO definition.

which results in the high pressure steam having a temperature of $501^{\circ} \mathrm{C}$ since the pinch temperature difference has a minimum value of $25^{\circ} \mathrm{C}$ in the high pressure (HP) superheater.

The optimum SCOC-CC has a relatively high pressure ratio, or around 57.3, and the turbine entry temperature is $1450^{\circ} \mathrm{C}$. Even though the pressure ratio is so high, the compressor outlet temperature is only $474^{\circ} \mathrm{C}$, which is below the temperature limit of the blade material. The steam turbine produces more of the power in the SCOC-CC compared to the reference cycle. The exhaust gas is cooled down from $618^{\circ} \mathrm{C}$ to $65^{\circ} \mathrm{C}$ in the HRSG. This comes from the fact that the working fluid achieves a better fit to the steam cycle. The main decrease in power comes from the $\mathrm{O}_{2}$ production and the $\mathrm{O}_{2}$ compression. The gross efficiency for the cycle is close to $60 \%$ but, taking into account the $\mathrm{O}_{2}$ production and compression, $\mathrm{CO}_{2}$ compression, and also the pumps, this is lowered to $46 \%$. The SCOC-CC cycle produces $10.3 \mathrm{~kg} / \mathrm{s}$ of $\mathrm{CO}_{2}$, which is about 890 tonnes per day. The SCOC-CC also produces about
$170 \mathrm{~kg} / \mathrm{s}$ of water with a temperature of $46^{\circ} \mathrm{C}$ in the flue gas condenser.

The optimum Graz cycle has a pressure ratio of about 36.5 and a turbine entry temperature of $1450^{\circ} \mathrm{C}$. Even though the pressure ratio is lower in the Graz cycle than in the SCOC$\mathrm{CC}$ and the compression is intercooled, the compressor outlet temperature is much higher or around $605^{\circ} \mathrm{C}$. The reason for such a high temperature is mainly the fact that the compressor inlet temperature is $100^{\circ} \mathrm{C}$. The working fluid saturation temperature is around $95^{\circ} \mathrm{C}$ so, to avoid condensation at the inlet of the compressor, the temperature needs to be higher than the saturation temperature. To be able to withstand the high temperature at the outlet of the compressor, the blade material will be more expensive than is normally used in compressors. The gas turbine produces a larger share of the power compared to the reference cycle and the SCOC-CC. This is because the cooling in the gas turbine uses steam from the steam cycle. The amount of steam needed for cooling is 
around $15.4 \mathrm{~kg} / \mathrm{s}$, which is about $50 \%$ of the steam produced in the steam cycle. This steam will therefore be expanded in the gas turbine and not in the steam turbine. This will have a negative effect on the efficiency since the steam will be expanded to 1 bar instead of 0.045 bar as it is in the steam turbine. One aspect of the Graz cycle is that the power density is much higher compared to both the reference cycle and the SCOCCC. The compressor inlet mass flow is only $40 \%$ of the reference cycle mass flow and $50 \%$ of that of the SCOC-CC. The gross efficiency for the Graz cycle is around 59\%. The major deduction in efficiency comes from the $\mathrm{O}_{2}$ production and compression. However, the compression power consumption is lower in the Graz cycle than the SCOC-CC because of the lower pressure ratio. The $\mathrm{CO}_{2}$ compression is similar to that in the SCOC-CC cycle. This results in nearly the exact same net efficiency as for the SCOC-CC or $46 \%$. The Graz cycle produces slightly more $\mathrm{CO}_{2}$, or around $10.8 \mathrm{~kg} / \mathrm{s}$, which is about 933 tonnes/day. The Graz cycle produces significantly more water than the SCOC-CC, or about $270 \mathrm{~kg} / \mathrm{s}$ of water with a temperature of $60^{\circ} \mathrm{C}$ in the flue gas condenser.

\section{Discussion and Conclusion}

The study compared three combined cycles, a conventional cycle, the SCOC-CC, and the Graz cycle, at the mid-size level power output. The gross power output for all cycles was set to $100 \mathrm{MW}$. The conventional cycle was used as the basis for the modelling and as a reference for the oxyfuel combustion cycles. A detailed literature review was conducted for the oxyfuel combustion combined cycles. The literature review showed that there is no consensus on the power requirement for the air separation unit. It also showed that the comparison of the SCOC-CC and the Graz cycle has lacked consistent assumptions and agreement on the technology parameters used to model the cycles.

A parametric study was conducted by varying the pressure ratio and the turbine entry temperature for the cycles. A constraint for the conventional cycle was set on the power turbine entry temperature to eliminate the need for cooling in the power turbine. The resulting optimal conventional cycle achieved a $56 \%$ net efficiency at a pressure ratio of 26.2 and a turbine entry temperature of $1400^{\circ} \mathrm{C}$. The optimal SCOC-CC achieved only a $46 \%$ net cycle efficiency at a pressure ratio of 57.3 and a turbine entry temperature of $1450^{\circ} \mathrm{C}$. The optimal Graz cycle also achieved a net cycle efficiency of $46 \%$ at a pressure ratio of 36.5 and a turbine entry temperature of $1450^{\circ} \mathrm{C}$. The main reduction in efficiency for the oxyfuel cycles comes from the $\mathrm{O}_{2}$ production, which reduced the power output from the cycles by more than $10 \mathrm{MW}$. An additional reduction of the power output comes from the compression of $\mathrm{O}_{2}$ to operating pressure. This is about $7 \mathrm{MW}$ and $6 \mathrm{MW}$ for the SCOC-CC and Graz cycle, respectively. The difference comes from the higher pressure ratio of the SCOC-CC.

One of the benefits of the Graz cycle is the high power density of the gas turbine. This results in smaller turbomachinery for the gas turbine in the Graz cycle, which lowers the cost of this machinery. One of the main penalties of the Graz cycle is that the large amount of steam, which is generated in the HRSG, is not expanded in the steam turbine but in the gas turbine. The result is that the steam does not expand to the condenser pressure of the steam cycle.

The SCOC-CC is considerably simpler than the Graz cycle as it does not implement steam cooling and does not require an intercooler. The optimal SCOC-CC, however, has a much higher pressure ratio than both the reference cycle and the Graz cycle. The efficiency does not vary greatly with the pressure ratio, however, and it is possible to reduce the pressure ratio without significantly penalizing the net efficiency. This would facilitate the compressor design substantially.

\section{Nomenclature}

$\begin{array}{ll}\alpha_{g}: & \text { Hot gas convective heat transfer coefficient } \\ \dot{m}^{*}: & \text { Dimensionless mass flow cooling } \\ \dot{m}_{c}: & \text { Cooling mass flow } \\ \eta_{c}: & \text { Cooling efficiency } \\ \eta_{C}: & \text { Cycle net efficiency } \\ \eta_{p}: & \text { Polytropic efficiency } \\ \eta_{\text {condenser }}: & \text { Condenser efficiency } \\ \lambda: & \text { Ratio of oxygen } \\ \rho_{g}: & \text { Hot gas density } \\ \text { St } g: & \text { Stanton number of the hot gas } \\ \varepsilon_{c}: & \text { Cooling effectiveness } \\ \varphi: & \text { Coolant mass flow ratio } \\ A_{b}: & \text { Blade area } \\ A_{g}: & \text { Annulus area } \\ C_{p, c}: & \text { Heat capacity of the cooling fluid } \\ C_{p, g}: & \text { Heat capacity of the hot gas } \\ p: & \text { Pressure } \\ \text { PR: } & \text { Pressure ratio } \\ R: & \text { Gas constant } \\ S: & \text { Turbine loss parameter } \\ s: & \text { Entropy } \\ T_{\text {bu }}: & \text { Uniform blade temperature } \\ T_{c e}: & \text { Cooling flow exit temperature } \\ T_{\mathrm{ci}}: & \text { Cooling flow inlet temperature } \\ T_{g}: & \text { Hot gas temperature } \\ \mathrm{TET}: & \text { Turbine entry temperature } \\ \mathrm{TIT}: & \text { Turbine inlet temperature } \\ \mathrm{ASU}: & \text { Air separation unit } \\ \mathrm{CCS}: & \text { Carbon Capture and Storage } \\ \mathrm{GT}: & \text { Gas turbine } \\ \mathrm{SCOC}-\mathrm{CC}: & \text { Semiclosed oxyfuel combustion combined } \\ \mathrm{ST}: & \text { cycle } \\ & \text { Steam turbine. } \\ & \end{array}$

\section{Conflict of Interests}

The authors declare that there is no conflict of interests regarding the publication of this paper.

\section{Acknowledgments}

This research was funded by the Swedish Energy Agency, Siemens Industrial Turbomachinery AB, GKN Aerospace, and the Royal Institute of Technology through the Swedish 
research program TURBOPOWER. Their support is gratefully acknowledged. The financial grant from Landsvirkjun's Energy Research Fund is gratefully acknowledged by the first author.

\section{References}

[1] IPCC, "2013: Summary for policymakers," in Climate Change 2013: The Physical Science Basis. Contribution of Working Group I to the Fifth Assessment Report of the Intergovernmental Panel on Climate Change, T. Stocker, D. Qin, G.-K. Plattner et al., Eds., Cambridge University Press, Cambridge, UK, 2013.

[2] B. Metz, O. Davidson, H. de Coninck, M. Loos, and L. Meyer, "IPCC special report on carbon dioxide capture and storage," Tech. Rep., Intergovernmental Panel on Climate Change, Working Group III, Geneva, Switzerland, 2005.

[3] F. Bolland, R. Naqvi, R. Span et al., "Public summary report of ENCAP delivarables D6.1.4 evaluation of technologies and benchmarking based on reference cases and D6.2.1 modelling, design and operational analysis," Tech. Rep., 2007, http://www .encapco2.org/.

[4] O. Bolland and S. Sæther, "New concepts for natural gas fired power plants which simplify the recovery of carbon dioxide," Energy Conversion and Management, vol. 33, no. 5-8, pp. 467475, 1992.

[5] I. Ulizar and P. Pilidis, "A semiclosed-cycle gas turbine with carbon dioxide-argon as working fluid," Journal of Engineering for Gas Turbines and Power, vol. 119, no. 3, pp. 612-616, 1997.

[6] I. Ulizar and P. Pilidis, "Design of a semiclosed-cycle gas turbine with carbon dioxide: argon as working fluid," Journal of Engineering for Gas Turbines and Power, vol. 120, no. 2, pp. 330$335,1998$.

[7] I. Ulizar and P. Pilidis, "Handling of a semiclosed cycle gas turbine with a carbon dioxide-argon working fluid," Journal of Engineering for Gas Turbines and Power, vol. 122, no. 3, pp. 437$441,2000$.

[8] O. Bolland and P. Mathieu, "Comparison of two $\mathrm{CO}_{2}$ removal options in combined cycle power plants," Energy Conversion and Management, vol. 39, no. 16-18, pp. 1653-1663, 1998.

[9] J.-M. Amann, M. Kanniche, and C. Bouallou, "Natural gas combined cycle power plant modified into an $\mathrm{O}_{2} / \mathrm{CO}_{2}$ cycle for $\mathrm{CO}_{2}$ capture," Energy Conversion and Management, vol. 50, no. 3, pp. 510-521, 2009.

[10] S. H. Tak, S. K. Park, T. S. Kim, J. L. Sohn, and Y. D. Lee, "Performance analyses of oxy-fuel power generation systems including $\mathrm{CO}_{2}$ capture: comparison of two cycles using different recirculation fluids," Journal of Mechanical Science and Technology, vol. 24, no. 9, pp. 1947-1954, 2010.

[11] K. Jordal, O. Bollard, and A. Klang, "Aspects of cooled gas turbine modeling for the semi-closed $\mathrm{O}_{2} / \mathrm{CO}_{2}$ cycle with $\mathrm{CO}_{2}$ capture," Journal of Engineering for Gas Turbines and Power, vol. 126, no. 3, pp. 507-515, 2004.

[12] R. E. Ulfsnes, O. Bolland, and K. Jordal, "Modelling and simulation of transient performance of the semi-closed $\mathrm{O}_{2} / \mathrm{CO}_{2}$ gas turbine cycle for $\mathrm{CO}_{2}$-capture," in Proceedings of the ASME Turbo Expo: Power for Land, Sea and Air, GT2003-38068, Atlanta, Ga, USA, June 2003.

[13] R. Ulfsnes, G. Karlsen, K. Jordal, O. Bolland, and H. M. Kvamsdal, "Investigation of physical properties of $\mathrm{CO}_{2} / \mathrm{H}_{2} \mathrm{O}$-mixtures for use in semi-closed $\mathrm{O}_{2} / \mathrm{CO}_{2}$ gas turbine cycle with $\mathrm{CO}_{2}$ capture," in Proceedings of the 16th International Conference on
Efficiency, Cost, Optimization, Simulation, and Environmental Impact of Energy Systems (ECOS '03), Copenhagen, Denmark, June 2003.

[14] G. Corchero, V. P. Timón, and J. L. Montañés, "A natural gas oxy-fuel semiclosed combined cycle for zero $\mathrm{CO}_{2}$ emissions: a thermodynamic optimization," Proceedings of the Institution of Mechanical Engineers Part A: Journal of Power and Energy, vol. 225, no. 4, pp. 377-388, 2011.

[15] T. Riethmann, F. Sander, and R. Span, "Modelling of a supercharged semi-closed oxyfuel combined cycle with $\mathrm{CO}_{2}$ capture and analysis of the part-load behavior," Energy Procedia, vol. 1, no. 1, pp. 415-422, 2009.

[16] H. J. Yang, D. W. Kang, J. H. Ahn, and T. S. Kim, "Evaluation of design performance of the semi-closed oxy-fuel combustion combined cycle," Journal of Engineering for Gas Turbines and Power, vol. 134, Article ID 111702, 2012.

[17] A. Dahlquist, M. Genrup, M. Sjoedin, and K. Jonshagen, "Optimization of an oxyfuel combined cycle regarding performance and complexity level," in Proceedings of the ASME Turbo Expo 2013: Power for Land, Sea and Air, GT2013-94755, American Society of Mechanical Engineers, San Antonio, Tex, USA, 2013.

[18] M. Sammak, E. Thorbergsson, T. Grönstedt, and M. Genrup, "Conceptual mean-line design of single and twin-shaft oxyfuel gas turbine in a semiclosed oxy-fuel combustion combined cycle," Journal of Engineering for Gas Turbines and Power, vol. 135, no. 8, Article ID 081502, 2013.

[19] H. Jericha, "Efficient steam cycles with internal combustion of hydrogen and stoichiometric oxygen for turbines and piston engines," International Journal of Hydrogen Energy, vol. 12, no. 5, pp. 345-354, 1987, CIMAC Conference Paper, Oslo, Norway.

[20] H. Jericha, W. Sanz, J. Woisetschläger, and M. Fesharaki, " $\mathrm{CO}_{2}$ retention capability of $\mathrm{CH}_{4} / \mathrm{O}_{2}$-fired graz cycle," in Proceedings of the CIMAC World Congress on Combustion Engine Technology, Paper G07, pp. 1-13, Interlaken, Switzerland, 1995.

[21] H. Jericha and E. Göttlich, "Conceptual design for an industrial prototype Graz cycle power plant," in Proceedings of the ASME Turbo Expo 2002: Power for Land, Sea and Air, GT2002-30118, American Society of Mechanical Engineers, Amsterdam, The Netherlands, June 2002.

[22] F. Heitmeir, W. Sanz, E. Göttlich, and H. Jericha, "The graz cycle-a zero emission power plant of highest efficiency," in XXXV Kraftwerkstechnisches Kolloquium, Dresden, Germany, September 2003.

[23] H. Jericha, E. Göttlich, W. Sanz, and F. Heitmeir, "Design optimization of the graz cycle prototype plant," Journal of Engineering for Gas Turbines and Power, vol. 126, no. 4, pp. 733$740,2004$.

[24] F. Heitmeir and H. Jericha, "Turbomachinery design for the Graz cycle: an optimized power plant concept for $\mathrm{CO}_{2}$ retention," Proceedings of the Institution of Mechanical Engineers Part A: Journal of Power and Energy, vol. 219, no. 2, pp. 147-155, 2005.

[25] W. Sanz, H. Jericha, F. Luckel, E. Göttlich, and F. Heitmeir, "A further step towards a Graz cycle power plant for $\mathrm{CO}_{2}$ capture," in Proceedings of the ASME Turbo Expo: Power for Land, Sea and Air, GT2005-68456, pp. 181-190, American Society of Mechanical Engineers, Reno, Nev, USA, June 2005.

[26] W. Sanz, H. Jericha, M. Moser, and F. Heitmeir, "Thermodynamic and economic investigation of an improved Graz Cycle power plant for $\mathrm{CO}_{2}$ capture," Journal of Engineering for Gas Turbines and Power, vol. 127, no. 4, pp. 765-772, 2005.

[27] M. H. Jericha, M. W. Sanz, and M. E. Goettlich, "Gasturbine with $\mathrm{CO}_{2}$ retention-400 MW oxyfuel-system Graz cycle," in 
Proceedings of the CIMAC World Congress on Combustion Engine Technology, Vienna, Austria, May 2007.

[28] H. Jericha, W. Sanz, and E. Göttlich, "Design concept for large output graz cycle gas turbines," Journal of Engineering for Gas Turbines and Power, vol. 130, no. 1, Article ID 011701, 2008.

[29] H. Jericha, W. Sanz, E. Göttlich, and F. Neumayer, "Design details of a $600 \mathrm{mw}$ Graz cycle thermal power plant for $\mathrm{CO}_{2}$ capture," in Proceedings of the ASME Turbo Expo: Power for Land, Sea and Air, GT2008-50515, pp. 507-516, American Society of Mechanical Engineers, Berlin, Germany, June 2008.

[30] H. Kvamsdal, O. Maurstad, K. Jordal, and O. Bolland, "Benchmarking of gas-turbine cycles with $\mathrm{CO}_{2}$ capture," in Proceedings of the 7th International Conference on Greenhouse Gas Control Technologies, vol. 1, pp. 233-242, Vancouver, Canada, September 2004.

[31] F. Franco, T. Mina, G. Woolatt, M. Rost, and O. Bolland, "Characteristics of cycle components for $\mathrm{CO}_{2}$ capture," in Proceedings of the 8th International Conference on Greenhouse Gas Control Technologies, Trondheim, Norway, June 2006.

[32] H. M. Kvamsdal, K. Jordal, and O. Bolland, "A quantitative comparison of gas turbine cycles with $\mathrm{CO}_{2}$ capture," Energy, vol. 32, no. 1, pp. 10-24, 2007.

[33] W. Sanz, H. Jericha, B. Bauer, and E. Göttlich, "Qualitative and quantitative comparison of two promising oxy-fuel power cycles for $\mathrm{CO}_{2}$ capture," Journal of Engineering for Gas Turbines and Power, vol. 130, no. 3, Article ID 031702, 2008.

[34] G. Woollatt and F. Franco, "Natural gas oxy-fuel cycles-part 1: conceptual aerodynamic design of turbo-machinery components," Energy Procedia, vol. 1, pp. 573-580, 2009.

[35] E. Thorbergsson, T. Grönstedt, M. Sammak, and M. Genrup, "A comparative analysis of two competing mid-size oxy-fuel combustion cycles," in Proceedings of the ASME Turbo Expo: Power for Land, Sea and Air, GT2012-69676, pp. 375-383, American Society of Mechanical Engineers, Copenhagen, Denmark, June 2012.

[36] P. Mathieu and O. Bolland, "Comparison of costs for natural gas power generation with $\mathrm{CO}_{2}$ capture," Energy Procedia, vol. 37, pp. 2406-2419, 2013.

[37] O. Bolland and H. Undrum, "A novel methodology for comparing $\mathrm{CO}_{2}$ capture options for natural gas-fired combined cycle plants," Advances in Environmental Research, vol. 7, no. 4, pp. 901-911, 2003.

[38] SimTech Simulation Technology, User Documentation: Program Modules and Model Libraries, IPSEpro Process Simulator, 2003.

[39] E. Thorbergsson, T. Grönstedt, and C. Robinson, "Integration of fluid thermodynamic and transport properties in conceptual turbomachinery design," in Proceedings of the ASME Turbo Expo: Power for Land, Sea and Air, GT2013-95833, American Society of Mechanical Engineers, San Antonio, Tex, USA, June 2013.

[40] G. Halls, "Air cooling of turbine blades and vanes: an account of the history and development of gas turbine cooling," Aircraft Engineering and Aerospace Technology, vol. 39, no. 8, pp. 4-14, 1967.

[41] M. J. Holland and T. F. Thake, "Rotor blade cooling in high pressure turbines," Journal of Aircraft, vol. 17, no. 6, pp. 412-418, 1980.

[42] K. Jordal, Modeling and performance of gas turbine cycles with various means of blade cooling [Ph.D. thesis], Department of Heat and Power Engineering, Lund University, 2001.
[43] O. Bolland and J. F. Stadaas, "Comparative evaluation of combined cycles and gas turbine systems with water injection, steam injection, and recuperation," Journal of Engineering for Gas Turbines and Power, vol. 117, no. 1, pp. 138-145, 1995.

[44] M. A. El-Masri, "On thermodynamics of gas-turbine cycles: Part 2-a model for expansion in cooled turbines," Journal of Engineering for Gas Turbines and Power, vol. 108, no. 1, pp. 151159, 1986.

[45] K. Jordal, L. Torbidoni, and A. Massardo, "Convective blade cooling modelling for the analysis of innovative gas turbine cycles," in Proceedings of the ASME Turbo Expo 2001: Power for Land, Sea and Air, GT2001-0390, American Society of Mechanical Engineers, New Orleans, La, USA, 2001.

[46] J. H. Horlock, D. T. Watson, and T. V. Jones, "Limitations of gas turbine performance imposed by large turbine cooling flows," Journal of Engineering for Gas Turbines and Power, vol. 123, no. 3, pp. 487-494, 2001.

[47] K. Jordal, Gas turbine cooling modeling - thermodynamic analysis and cycle simulations [Licentiate thesis], Department of Heat and Power Engineering, Lund University, Lund, Sweden, 1999.

[48] R. C. Wilcock, J. B. Young, and J. H. Horlock, "The effect of turbine blade cooling on the cycle efficiency of gas turbine power cycles," Journal of Engineering for Gas Turbines and Power, vol. 127, no. 1, pp. 109-120, 2005.

[49] M. Mallen and G. Saville, Polytropic Processes in the Performance Prediction of Centrifugal Compressors, I. Mech. E. Conference Publications, Institution of Mechanical Engineers, London, UK, 1977.

[50] W. Traupel, Thermische Turbomaschinen, Springer, Berlin, Germany, 1977.

[51] F. Di Maria and K. Jordal, "Blade cooling model comparison and thermodynamic analysis," in Proceedings of the 5th ASME/JSME Joint Thermal Engineering Conference, AJTE99-6117, American Society of Mechanical Engineers, San Diego, Calif, USA, March 1999.

[52] A. Dahlquist, M. Thern, and M. Genrup, "The inuence from the working medium on the profile loss in compressor and turbine airfoils," in Proceedings of the ASME Turbo Expo 2014: Power for Land, Sea and Air, GT2014-25069, American Society of Mechanical Engineers, Düsseldorf, Germany, 2014.

[53] S. G. Sundkvist, A. Dahlquist, J. Janczewski et al., "Concept for a combustion system in oxyfuel gas turbine combined cycles," Journal of Engineering for Gas Turbines and Power, vol. 136, no. 10, Article ID 101513, 2014.

[54] I. Pfaff and A. Kather, "Comparative thermodynamic analysis and integration issues of CCS steam power plants based on oxycombustion with cryogenic or membrane based air separation," Energy Procedia, vol. 1, pp. 495-502, 2009.

[55] J. Tranier, N. Perrin, and A. Darde, "Update on advanced developments for ASU and $\mathrm{CO}_{2}$ purification units for oxy-combustion (air liquide, France)," in Proceedings of the 3rd Meeting of the Oxy-Fuel Combustion Network, IEAGHG International OxyCombustion Network, Yokohama, Japan, March 2008.

[56] K. Jeong, M. J. Kessen, H. Bilirgen, and E. K. Levy, "Analytical modeling of water condensation in condensing heat exchanger," International Journal of Heat and Mass Transfer, vol. 53, no. 1112, pp. 2361-2368, 2010. 

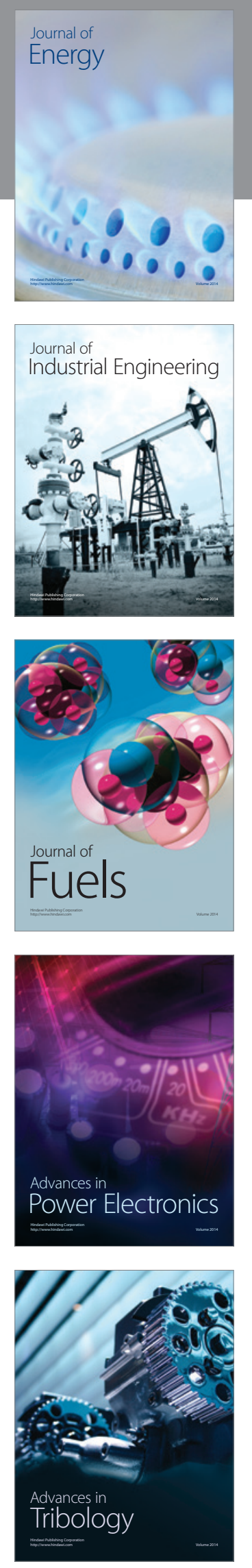
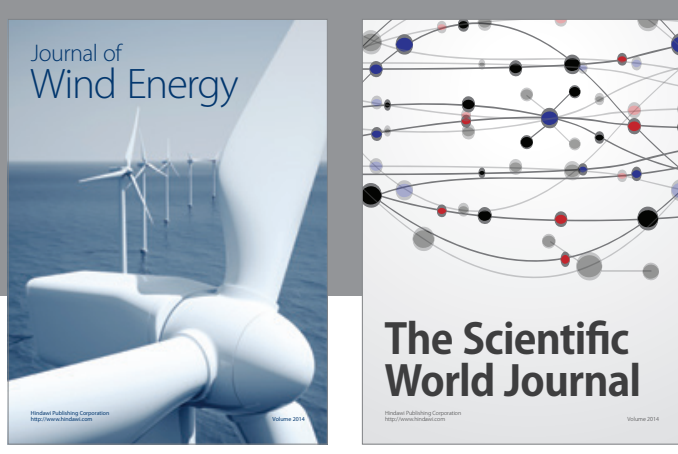

The Scientific World Journal
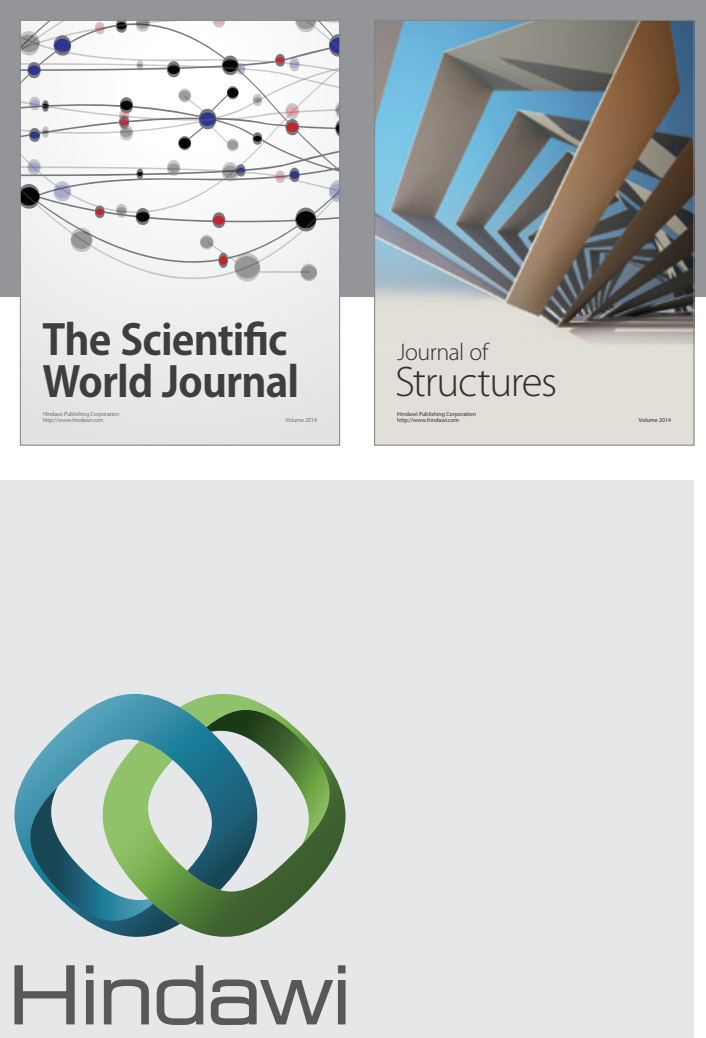

Submit your manuscripts at

http://www.hindawi.com
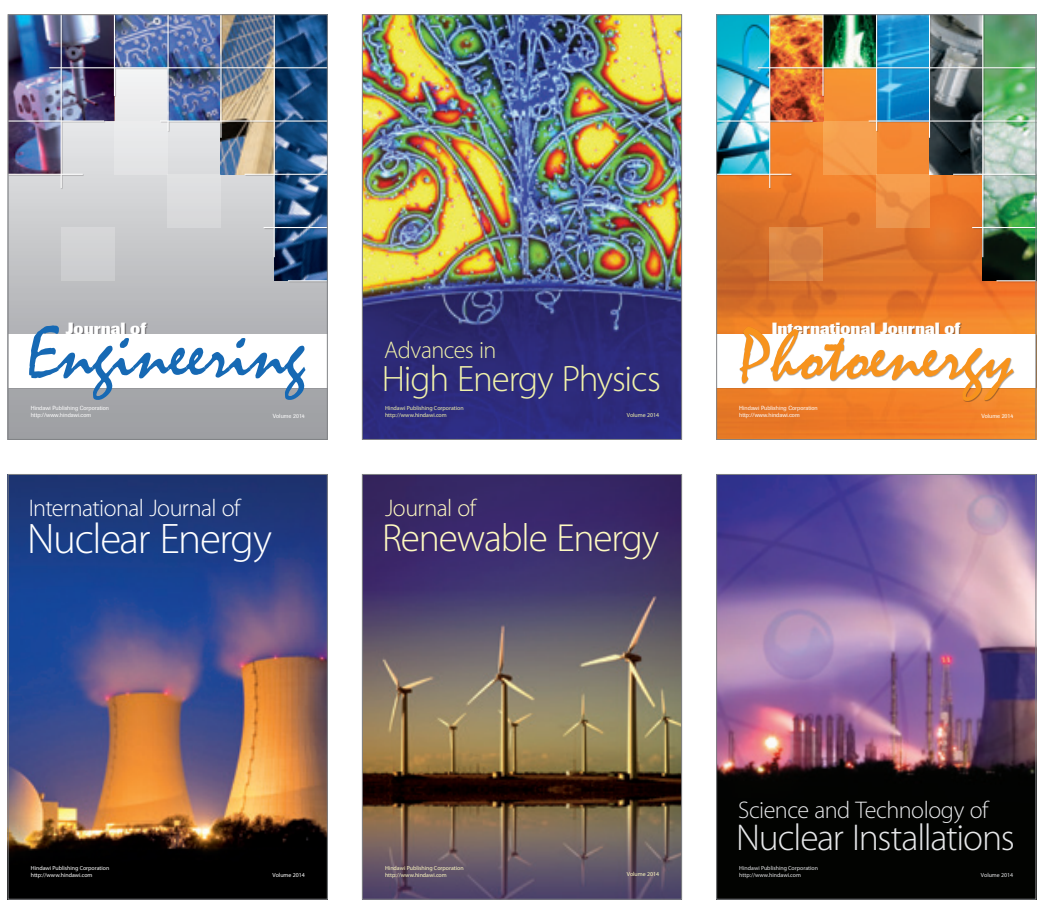
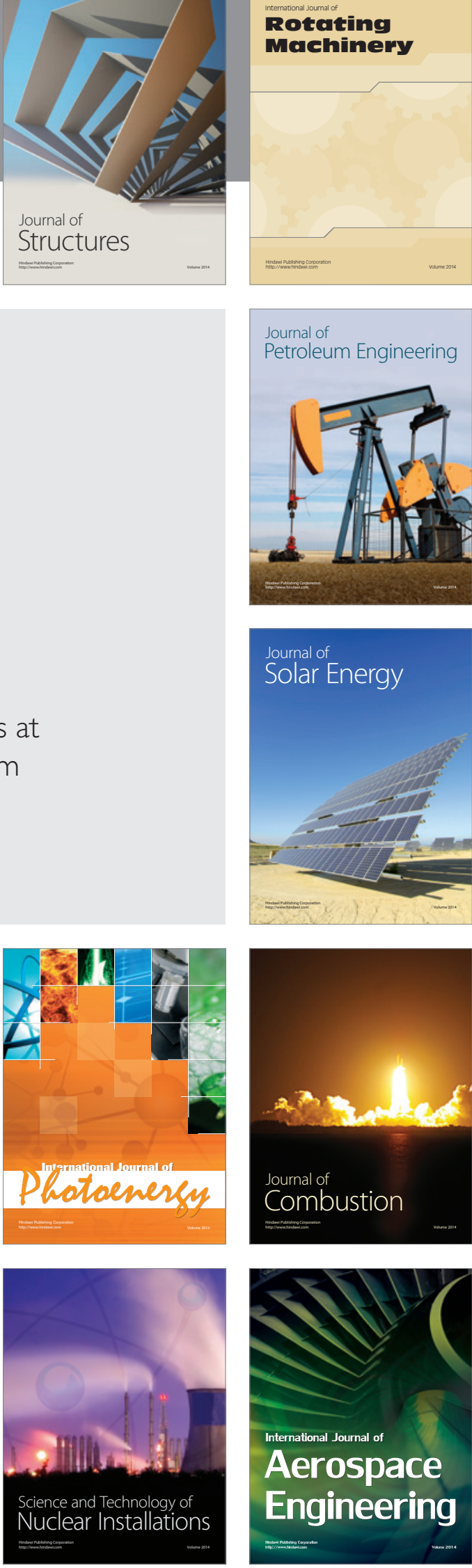